OPEN ACCESS

Citation: Katalin Kempf, Beatrix Vincze, Németh András (2020) Challenges in Museum Education, Best Practices in Hungary. Rivista di Storia dell'Educazione 7(2): 121-131. doi: $10.36253 /$ rse-9830

Received: October 6, 2020

Accepted: October 30, 2020

Published: January 25, 2021

Copyright: ( 2020 Katalin Kempf, Beatrix Vincze, Németh András. This is an open access, peer-reviewed article published by Firenze University Press (http://www.fupress.com/rse) and distributed under the terms of the Creative Commons Attribution License, which permits unrestricted use, distribution, and reproduction in any medium, provided the original author and source are credited.

Data Availability Statement: All relevant data are within the paper and its Supporting Information files.

Competing Interests: The Author(s) declare(s) no conflict of interest.

Editor: Pietro Causarano, Università di Firenze.

\section{Challenges in Museum Education, Best Practices in Hungary}

\section{Sfide nell'educazione museale, migliori pratiche in Ungheria}

\author{
Katalin Kempf, Beatrix Vincze, Németh András
}

Eötvös Loránd University, Hungary

E-mail: kempf.katalin@ppk.elte.hu; vincze.beatrix@ppk.elte.hu; nemeth.andras@ppk. elte.hu

\begin{abstract}
The study aims to present the best practices of museum education, art pedagogy and circus pedagogy in Hungary, to highlight their importance and their role as mediators of cultural values and their role in social equal opportunities. It emphasizes the role of non-formal forms of learning that are capable of meeting learners' needs in a well-defined, differentiated, and experiential way outside the school system. At the same time, the study reflects on current issues in the renewal of museum education. Among other things, for those who want to study, «everything is more interesting outside of school». Changing learning habits and technical opportunities poses a major challenge in sustaining learning motivation. It also emphasizes the potential of informal learning in diverse settings - family, community, informal and supportive of information acquisition and capacity building (Coombs 1969, 1972). It cites examples of good domestic practice as interpreted by the Constructivist Museum (Anderson 2008; Black 2012; Hein $2004 \mathrm{a}, \mathrm{b}$ ) and refers to programs, projects, and circus pedagogical initiatives for SEN and disadvantaged groups.
\end{abstract}

Keywords: museum education and training, non-formal learning and teaching, circus pedagogy, art pedagogy, special education needs.

Riassunto. Lo studio mira a presentare le migliori pratiche di educazione museale, pedagogia dell'arte e del circo in Ungheria, per evidenziare la loro importanza e il loro ruolo di mediatori di valori culturali e il loro ruolo nelle pari opportunità sociali. Esso sottolinea il ruolo delle forme non formali di apprendimento che sono in grado di soddisfare i bisogni degli studenti in un modo ben definito, differenziato ed esperienziale al di fuori del sistema scolastico. Allo stesso tempo, lo studio riflette sulle questioni attuali nel rinnovamento dell'educazione museale. Tra le altre cose, per chi vuole studiare, "tutto è più interessante al di fuori della scuola". Il cambiamento delle abitudini di apprendimento e delle opportunità tecniche rappresenta una grande sfida per sostenere la motivazione all'apprendimento. Sottolinea anche il potenziale dell'apprendimento informale in diversi contesti - famiglia, comunità, informale e di supporto all'acquisizione di informazioni e allo sviluppo di capacità (Coombs 1969, 1972). Cita esempi di buone pratiche domestiche come interpretate dal Constructivist Museum (Anderson 2008; Black 2012; Hein 2004 a, b) e si riferisce a programmi, progetti e iniziative pedagogiche circensi per SEN e gruppi svantaggiati.

Parole chiave: educazione e formazione museale, apprendimento e insegnamento non formale, pedagogia circense, pedagogia dellarte, esigenze educative speciali. 


\section{INTRODUCTION}

How do we define museum pedagogy? Museum pedagogy is a special area of educational science that has a relatively long history. Its development is closely related to the reform pedagogical schools, the didacticmethodical characteristics of the child anthropological, and the life reform movements. Museum pedagogy is an important place for extracurricular education, a pedagogical educational activity for extracurricular knowledge transfer, based on the museum collection and exhibition, built on formal, formal education and attends to age-related characteristics.

In general terms, it is the pedagogy with the help of the museum; it includes a wide variety of forms of education, which can take place in the museum, starting from the museum or partly in the school. According to B. Lord and G. D. Lord, «museum learning is an informal, voluntary experience in which we develop new attitudes, interests, assessments, beliefs or values» $(2007,17$ quoted by Koltai 2010, 51).

Historical development played a significant role in the definition of museum pedagogy. The traditions of the German language area and the Anglo-Saxon museums were also important in this scientific field. The German Alfred Lichtwark (1852-1914) and the American John Dewey (1859-1952) were considered as two great forerunners of museum pedagogy. From the 1890s onwards, art education came to the fore in Europe, with the help of which students were prepared to receive fine art. Art education mainly took place in drawing classes, but it also appeared in a complex form in reform pedagogical schools such as the Waldorf pedagogy and Jenaplan Schools. Lichtwark, the Hamburg art historian and museum director, saw the purpose of art education as follows: «[...] we do not want a museum that stands and waits, but an institution with a say in the artistic education of the population» (German 2015, 3). In addition to the school, Lichtwark considered the museum to be a place of artistic education and wanted to make the works of art acceptable to both children and laypeople. Lichtwark did not want to illustrate, he wanted to talk about the works (Schütz 2002).

Lichtwark had on effect Julius Langbehn (18511907), published his book Rembrandt as an educator in 1889. Langbehn emphasized Rembrandt's follow-up. Konrad Lange (1855-1921) wrote about The Art Education of German Youth (1893). He identified the development of an art sensitive audience as a prerequisite for the rise of German culture. The art education movement, which was part of the life reform movements that unfolded mainly in The German language, created regu- lar children's drawing exhibitions and art educational conferences. The German influence was very important for the Hungarian museum pedagogy too. Children's drawing exhibitions were organized in Hungary at the beginning of the $20^{\text {st }}$ century. The art education of children took part in the pedagogical debates in the interwar period (Joó 2014).

John Dewey defined the pedagogical relationship between museums and school education as a direct link in his 1912 work The School and Society. Dewey presented the «school of the future» in which the formal education got new features. His principle was «learning by doing». The Laboratory School in Chicago partially tried the new form of education. There was a centrally located workshop, kitchen, and library next to the museum. According to Dewey, the main role of the school is preparation for life (Németh 1996; Koltai 2012).

The German terminus underlined that museum education is an interdisciplinary science, which is a borderline science that touches on both areas of museology and educational science. In particular, the areas of general pedagogy, school pedagogy, adult pedagogy as well as play and theatre pedagogy are to be mentioned here (Tripps 1990, 5). Hümmer underlined the following: «Museum education as a mediation activity begins as soon as a museum is accessible to the public» (1980, 27). The objective is of conceptually and thematically designed museums with the help of a comprehensive set of media instruments to reach the different populations. The museums should be able to attract interest from heterogeneous groups and overcome the cultural barriers between them (Binkowski 2009). Because museum didactics is also responsible for the selection of the objects to be shown, and museum education explicitly aims to promote personality. Moreover, it has a strong connection to psychology, too (Herles 1998, 38).

The American Association of Museums ${ }^{1}$ defined in his report $\mathrm{t}^{2}$ the key role of museums: «the educational role of museums is at the core of their service to the public» (Hirzy 1992, 11). According to the report, «[...] the public dimensions yf museums lead them to perform the public service of education - a term that in its broadest sense includes exploration, study, observation, critical thinking, contemplation, and dialogue» (Hirzy 1992, 12).

Museum pedagogy is a form of knowledge transmission based on pedagogical and didactic means, which takes place in various medial and personal forms on one hand. In the narrow sense, the medial transmission includes "visual collections", captions, graphics, photos, videos, films, computer animations, dramatized

\footnotetext{
${ }^{1}$ Now it calls the American Alliance of Museums.

${ }^{2}$ The title of this report was Excellence and Equity.
} 
spatial representations, catalogues, information sheets. In a broader sense, personal mediation includes guided tours, demonstrations, games, project works, excursions, courses, special additional activities (Vieregg et al. 1994).

Museum pedagogy is an institutionalized pedagogical activity and is based on the elements of informal learning, which adapts to the postmodern reality of the $21^{\text {st }}$ century. Today's cultural diversity has transformed the traditional role of museums, complementing the development of elements of social sensitivity and social harmony.

In the $19^{\text {th }}$ century, the modern museum ideal broke with the old tradition of museums keeping only objects. Since the 1960s, reflections on the institution and the collection have become increasingly prominent, transforming the image of the museum, which has transformed the way museums operate and their image to the outside world. Today, in most museums, the emphasis has shifted from culture, knowledge enhancement, and knowledge transfer to the sensory-oriented museum pedagogy using interactive methods. In addition to the scientific focus, the role of the museum experience has been appreciated. The $21^{\text {st }}$ century has been a key part of the world. Museology is constantly facing new challenges too (Germán 2015).

With the importance of museum pedagogy and domestic reflections in mind, we undertake to answer the following questions: How museum pedagogy adapts to the $21^{\text {st }}$ century postmodern challenges: technical renewal (ICT), changed learning-teaching strategies, new expectations of the museum (edutainment)? How has the relationship between the school and the museum changed? How does the Hungarian museum pedagogy and training reflect the changing needs for museum pedagogy?

\section{CHALLENGES FOR EDUCATION AND MUSEUM EDUCATION IN THE $21^{\text {ST }}$ CENTURY}

The global challenges of the millennium have put education at the heart of the issue. The available knowledge is appreciated, and economic and social challenges are brought to the foreground in a way that can be used in practice. Already in the UNESCO report of 1972, in which Delors underlines the need to learn the methodology of learning (to learn to know) and to learn to work with the right skills and skills (learning to do) to have a proper impact on the environment. In order, to successfully collaborating with other fellow human beings, you need to learn to live together. Moreover, in a successful life you need to be able to live (learning to live), that is, we can only live a full and responsible life by learning to live. (Delors 1972/1997)

Public education of the $21^{\text {st }}$ century brought to light other problems. The education-focused school is in crisis. Some disciplines are "on the run" (language, information technology) and traditional subjects disappear (Greek, Latin), loose (natural sciences), some difficult to identify (communication, economic and civic knowledge). There is a significant contradiction between transdisciplinary knowledge production and strictly the subject system. It is difficult to integrate new cultural elements (image, internet, EQ, spiritual and health culture, market youth culture) into school education, but they are becoming more important. There are a growing student inflexibility and teacher confusion. According to several studies, the time spent at school is proportional to the motivation of students and the less popular, "difficult" science subjects (physics, mathematics, and chemistry) or grammar. However, negative learning attitudes can also be observed in the more popular subjects (literature, biology, geography, or drawing) (Halász 2001; Setényi 2009). During the school years, more and more pupils are experiencing a decrease in learning, and a sizable proportion of students consider the school to be a prison-like institution, and learning is seen by the student as a passive, forced and boring activity (Golnhofer 2003).

Changes in the environment of learning in the $21^{\text {st }}$ century. Learning can take place in different locations, in different situations. Thanks to the digital revolution, ICT will become an increasingly important element of learning situations. Learning takes place in networks and groups. Self-study planning and decision-making will be appreciated. Group performance becomes important (Moskal, Patsy and Charles, Dzubian 2001; Setényi 2009). In the public education of the $21^{\text {st }}$ century, sustainability as a whole approach to pedagogy is gaining ground in education. In its pedagogical renewal, the criteria for sustainable education are the following: «the approximation of real-life to the school; a description of the fundamental problems and causalities of nature, society, and economy; conveying knowledge that can be used by learners; promoting the development of learners into a responsible citizen». (Kovátsné 2006) How changes the task of museums?

Nowadays, museums have the task of not only storing and preserving historical values but also of using them for learning purposes. From the perspective of educational sciences, learning in museums is one form of situated learning, where access to a variety of knowledge is possible, providing learning opportunities that enhance individuals' interest in knowledge accumulated in museums, 
interacting with virtual artefacts, and enabling them to interact with substance and concreteness with the museum's intangible artefacts (sum of Daniela 2020).

Learning in museums can support culturally responsive teaching. Today museums can use virtual technics and technologies. This new performance leads up to the difference between idea and reality. By the second half of the $20^{\text {th }}$ century, the traditional three-way task of museums for collecting, preserving, and exhibiting started to have new functions and mediation has become a priority: the shift in emphasis from the subject to the action increases the importance of the building and the events (Koltai 2011).

The essence of postmodernism (used from 1960), according to Jean-François Lyotard: «To oversimplify, I define "postmodern" in distrust of great narratives». (Lyotard 1993, 8) Lyotard's thinking is that meta-narratives were used to sustain the institutions of the existing social system, which gave their ideological background. The main feature of postmodernism is distrust and uncertainty, that the experience is incidental, the reality is fragmentary and unknowable, history has no direction, the individual has no stable identity, changing manner of speeches and perspectives alternate. The essence of postmodernism, therefore, is to call into question the individual identity of the subject and the existence of uniform, absolute world-explaining principles (ad-hoc), the world is ambiguous, heterogeneous, selfcontradictory, which necessarily expresses the role and function of museums in a change of a function (Pásztor 2000, 259).

The imprints of the twists and turns of the second half of the $20^{\text {th }}$ century had a strong influence on the museum world. Among them are the visual turns (texts), the space turn (new plains of space and time), the visual turn (the symbols), and the performative turn (collective cultural manifestations) that have provoked a crisis. These have not only given way to the reimagining of the exhibition, but also the reimagining of the texts. In recent decades, the relationship between museums and local society has changed, because, in today's globalized world, museums play a role in building local communities and preserving local traditions, and strengthening local identity (Hooper-Greenhill 2004; Koltai 2011).

However, an important function of museums is the preservation of ethnic and cultural identity today. Lifelong learning supports the new function of museums, and it is now a new challenge for them to learn how to get involved in the information web, what opportunities they can find to meet the requirements of the edutainment in cyberspace with their virtual exhibitions and programs. Based on the wide range of services, there are anthropological museums (Ébli 2009), open museums (Frazon 2018), and participation museums (Simon 2010).

American museums lead by many good examples, such as the Smithsonian, the Metropolitan, and the Exploratorium. On their websites, these museums contain draft lessons, databases, and educational aids that can be used by teachers to work with students, integrate them into the curriculum, effectively linking learning opportunities based on the collection and the knowledge accumulated there with formal learning within the school framework (Koltai 2011).

According to Weil (2000), in addition to the previous functions of museums, collection, research, and exhibition, as well as education and recreation, new features are added, resulting in institutions becoming visitor-centred rather than museum-centric. The new additional features that are not directly related to the institutional collection, such as a café or museum shop. According to Weil (1990), museums now complement their traditional functional role with their expedient, intended role. Weil's functional role understands traditional activities such as collection, preservation, communication, and exhibition for artistic, educational, and educational purposes. By targeted and intended function, he means that the museum is designed to entertain people and to learn from the collections (Gombos 2011). Museum experts have also realized today that they need to change to increase the number of visitors and attract young people to the museum. More and more special events are increasing the popularity of museums, such as Night of Museums, Autumn Night of Museums, the Autumn Festival of Museums, and Museum Maying. Unfortunately, the new performances do not necessarily mean that museum visits will become more popular in the rest of the year (Gombos 2011).

David Carr emphasizes the importance of valuesharing and the authoritarianism of museums about the functioning of museums in society. In his vision, museums and libraries should encourage us to discover the imperfect nature of our lives and ask ourselves more questions. Museums must become places that help to explore the mind and which see knowledge as a process, not a complete thing (Carr 2001). In other words, according to the constructive pedagogical paradigm, he describes such institutions as "opportunity-creating" spaces, where the objects and exhibitions in it serve as a springboard to «deepen thinking and ask courageous questions».

In a globalized world, thanks to the ongoing "digital revolution", people are getting more and more information. The consumption of culture has also become an interactive process. Museum visitors, as cultural consum- 
ers, are transforming the offer of museums with their needs, as they constantly expect something new (new services) from the institutions. Meanwhile, museums are using new marketing tools to win more visitors. In this "new world", you have to meet both visitor and professional expectations. It is also a major challenge that the cultural consumption of the young generation is low, but older people have a higher need for culture. Bridging the generational gap between the ages also imposes new tasks on museum professionals (Gombos 2011; Koltai 2011).

Cultural consumption patterns have changed considerably, the culture consumption space has been moved to the virtual space, i.e. between the "four walls", with the consequence that the sacral nature of culture disappears, and it is increasingly possible to take culture home (Hunyadi 2005).

In the early $21^{\text {st }}$ century, we witnessed a paradigm shift. There is such a huge difference between the students of the $20^{\text {th }}$ and $21^{\text {st }}$ century that it creates new demands for an education that can no longer be implemented by traditional methods. Education systems have been and will be under increasing pressure since the turn of the millennium to integrate various technological tools and methods of experiential education (Molnár 2011).

\section{NON-FORMAL EDUCATION, CONTACT BETWEEN MUSEUMS AND SCHOOLS}

Museums can understand, develop, expand, and use the learning opportunities. They offer their visitors the diversity of non-formal education activities. The different forms of museums should constitute an important complement to formal education and the total educational efforts. Coombs underlined the importance of non-formal education (1969). He considered that nonformal education had the potential to satisfy the learning demands of both, individuals and collectives. By non-formal education, Coombs means a definite form of learning outside the school system in an organized framework, whereas informal learning takes place in a diverse set of colours - family, community level - and is informal and involves information acquisition and skills development. In contrast to formal (traditional) education, which is institutional learning and closed with a diploma and professional qualification, non-formal education (learning) is flexible. Coombs has strengthened the learning focus of the lifelong learning paradigm $(1969,1972)$. It can reflect on local variations of culture, economy, and society (OECD, 1996, 2020) ${ }^{3}$. It can offer variable planning and designing educational activities. Moreover, it is reached on out-door activities, which have popularity among children and adults, too. The potential for non-formal learning can be a place of work or school, but can also take place in the context of the activities of civil society organisations (e.g. youth organisations, trade unions, political parties). It may also take place through organisations or services (e.g. fine arts, music courses, sports education, or private examination training) which have been set up to complement formal systems (Memorandum of Commission of the European Communities 2000).

From the learners' perspective, the former learning is characteristically teacher-controlled and compulsory, while the informal form is a spontaneous, student-driven learning process, often related to leisure or cultural activities. Non-formal learning refers to the transition between the two: learning processes are outside the school walls but in the course of organized and structured activities. Learning is carried out under the guidance of an instructor or facilitator, but in a more flexible and open form than formal learning (Eshach 2007).

Both formal and non-formal learning are targeted, whereas informal knowledge is not necessarily conscious, and therefore indirect or secondary learning is involved. On this basis, some of the researchers classify learning in different extra-curricular scenes, such as a park, zoo, museum, factory, experience laboratory, into the informal category, although this is questionable. Out-of-school learning (non-formal) is particularly effective for pupils who are lagging or underperforming and are less motivated in traditional classroom conditions and therefore have learning difficulties. Out-of-classroom scenes can be a good learning alternative for these students by giving them the opportunity to the "aha experience" and instant success (Füz 2018; Halász 2001; Farkas 2014; Bereczki and Népessy 2020).

Our built and natural environment can be a possible place for extracurricular learning. Various cultural institutions such as museums, galleries, libraries, visual

\footnotetext{
${ }^{3}$ OECD defined the formal, non-formal and informal learning: «Formal learning is always organised and structured, and has learning objectives. From the learner's standpoint, it is always intentional: i.e. the learner's explicit objective is to gain knowledge, skills and/or competences. Informal learning is never organised, has no set objective in terms of learning outcomes and is never intentional from the learner's standpoint. Often it is referred to as learning by experience or just as experience. Mid-way between the first two, non-formal learning is the concept on which there is the least consensus, which is not to say that there is consensus on the other two, simply that the wide variety of approaches in this case makes consensus even more difficult. Nevertheless, for the majority of authors, it seems clear that non-formal learning is rather organised and can have learning objectives».
} 
laboratories, scientific centers, zoos, botanical gardens, or the natural environment: national parks, trails, forests, fields, waterfronts can be used as places of learning. Moreover, an economic plant or factory can be the place of education, where learners can study the processes in reality by conflicting different points of view, and thereby they can be motivated to learn system-oriented (Black 2012; Fägerstam 2012; Füz 2018; Waite 2011).

Museums and science centers are special sites that can bridge the gap between often seems too complex and abstract scientific achievements, data, and the public. They make science understandable and accessible to laypeople. Museum lessons are excellent for reducing academic segregation and complex, project-based processing of a particular topic improves the understanding of context and system-based thinking (Black 2012; Fägerstam 2012; Füz 2018; Waite 2011).

The learning in the museum has specialities, which were summarized by Kelly (2007). His "6P-model" defined six elements: person, purpose, process, people, place, and product. Parts of the process of museum learning: (a) the "person" (individual learning), the individual's previous knowledge, cultural and social environment, daily life, past, the framework of interpretation; b) the "purpose": motivations behind learning, interests, choice preferences, enjoyment; c) the "process": an infinite number of ways of learning. During the "do something", the use of objects and tools, cognitive and psychological levels prevail at the same time; d) "people": the social dimension of learning, i.e. family influences, the influence of friends, colleagues, the role of accompanying adults, the impact of the community, the presence of professionals (museum staff, teachers); e) the "place": where does the learning take place? Formal or informal locations? School, museum, gallery, cultural institutions, libraries, internet, nature, the museum is a reliable source of knowledge; $f$ ) the "product": the result of learning (Kelly 2007).

After the turn of the millennium, the challenges of globalization led to new social functions as part of the cultural "shopping centres" of the big cities as «open museums as multifunctional open areas for the postmodern urban public. Improving local quality of life increased cultural offers; preservation of cultural heritage; the various forms and promotions of cultural activity. They focus on schools; active community, urban social life, cultural events, and experiences (city holidays, festivals); the location where local identity is displayed; market consumer aspects» (König 2002).

In addition to formal learning, museums play an important role in informal learning. Formal learning is the form of knowledge acquisition that takes place within the school framework, usually in the framework of teacher-directed, organized, and structured knowledge acquisition. While informal learning is learning driven by a spontaneous, non-direct learning goal, which is often hidden from the individual (Elwick 2013). In the real-life, it is not easy and unproblematic to carry into execution the contact between the museums and schools. Visiting museums has long traditions, but interesting and learning needs change from day to day (Vásárhelyi 2010).

The Hungarian school system does not provide enough connections between the subjects and the students, and it can put in a context very difficult the lessons they learn in school with everyday life (Csapó 1999). However, extracurricular occupations promote the experience of real-life and are well suited to integrate different subjects. Learning through real-world experiences results in a deeper level of knowledge. Authentic color spaces outside the school allow students to combine theoretical and experience-based, practical knowledge. The learner can pick up knowledge and experience, in continuous interaction. Cognition is supported by various sensory perceptions, not only vision and hearing but also whether it is palpation, smell, and taste. Extracurricular education is much more effective than between the walls of the school. There is more time, a more informal atmosphere, but most of all the participants have their own experience, the acquisition of experience. It has a deeper, more lasting effect since during the experience the child becomes a part of the activity, thus the own experience leads to the emotional attachment (Vásárhelyi 2010).

In summary, we can underline that out-of-school learning differs from traditional school learning as follows: a) a natural or lifelike environment provides an experience-rich and information-rich context for learning; b) offers a variety of work and testing tools instead of the usual teaching tools; c) acts on several senses at the same time; d) new and diverse spaces provide an opportunity to use open pedagogical methods based on student activity and cooperation; e) specific practical experience is more pronounced rather than theoretical; (f) pupils and teachers often present with unexpected situations and problems; more open and flexible than classroom hours (Eshach 2007).

If we compare the specifics of school to museum learning, we can say that the museum provides the ground for non-formal and informal learning in the $21^{\text {st }}$ century. It is an important tool for school innovation. The training of Museum Education is very important not only for museums but also for schools. The Hungarian Museum Education began his spectacular develop- 
ment in 1970 years. Today, more than fifty vocational museum courses in Hungarian higher education (with more thematic characteristics) offer learning opportunities in museums or art education. Among the courses of the faculty of philosophy, there are optional museum courses. Museums provide several courses in the framework of EU projects, which provide no qualifications (degree) but are retraining and free of charge.

\section{GOOD PRACTICES OF MUSEUM EDUCATION, ART PEDAGOGY, AND CIRCUS PEDAGOGY IN HUNGARY}

Our institution, Eötvös Loránd University, has been organizing museum pedagogical training for more than 20 years, so we can say that we have an active relationship with Budapest museums with a significant history, which extends beyond training to joint research.

Hungarian training also reflects on the changing nature of museums and their increasing social responsibility. Cultural diversity, the effects of social processes, steps to involve groups that do not study museums and its methodology challenge the museum educator (Curriculum 2017) ${ }^{4}$.

The aging of society, which has brought to the forefront Europe-specific programs to promote activity, knowledge conservation and enrichment, and the common museum "well-being" of several generations (Koltai 2020).

Some of the good practices are highlighted (mainly from museums in Budapest), which, on the one hand, follow international trends and reflect on local characteristics on the other hand. As an adjunct to school education, museum, and art pedagogy as a special pedagogical area is capable of enabling not only children with special needs to be received in integrated groups, but also play a significant role in increasing attitudes and tolerance of adults.

In Hungary, programs for dementia patients and grandparents and grandchildren are also present at the Open-Air Ethnographic Museum, the Aquincum Museum, but also at the Smidt Museum in Szombathely. The National Museum of Liverpool's Dementia Programme (2012) is a sample that provides a memory walk or memory suitcase for dementia users. They use images or objects to stimulate memory and facilitate conversations.

The Ludwig Museum in Budapest, together with the Maltese Charity, organizes museum pedagogical activities for homeless groups. The Ludwig Museum's Inte-

\footnotetext{
${ }^{4}$ The Curriculum of Training of Education in Museum is available on the page of Eötvös Loránd University: https://www.ppk.elte.hu/file/ ismerteto_muzeumpedagogia_20170.pdf
}

grated Family Morning program belongs to the best practices, which is for children with disabilities and their families. This initiative seems to be exemplary and niche. The key to development is to increase the number of occupations based on multisensory ability because not only visitors with special needs can be brought closer to the works of art, but also the elderly have a better chance so that everyone will enjoy the experience of visiting in a museum. "We'll see" project's creators are guides on the exhibition "Our Common Affairs" of Ludwig Museum. Visually impaired creators of the project hold an exclusive guided tour, then space becomes a common creative workshop, and visitors can take part in a creative workshop. In cooperation with the Institute of the Blind of Budapest, five artists worked with visually impaired people. Working together was actually like self-awareness training. Artists usually work independently, invent a concept, and implement it. In this project, however, it required very close cooperation, and this was new to artists. During the collaboration, the artists learned more and more about themselves, but also of their fellow creators, so everyone became sensitive in this process (Somogyi-Rohonczy 2019).

Regarding disadvantaged groups, the institutions need to be developed almost everywhere, both at home and internationally. Based on the good examples collected by the research of the Museum Centre for Education and Training in Szentendre (2017), a methodology for the reception of people with comprehension difficulties, the disabled and the visually impaired has been completed (Dabi-Farkas 2018). The analysis of Hungarian institutes was most recently carried out by the SZNM MOKK (Open-Air Ethnographic Museum, Museum Education, and Methodological Centre) in this area in 2017. Hungarian museums (among them Open-Air Ethnographic Museum in Szentendre), which build and use an accessibility strategy in the spirit of "museums for all", can provide a vision in which all members of society can be accommodated, have a suitable environment and communication to achieve the right information and experiences that are understandable to them. A national museum quantitative and qualitative in-depth interview was carried out as part of the museum and library development project for all. Taking into account the principle of "Nothing about us without us" (Advocacy, MEOSZ 2017), the experts of museum stress that museum programs and methodologies used are not therapeutic, healing developments. Their programs based on research are pedagogical activities in the museum, which uses several special pedagogical methodological elements and/or special communication, other than the general museum pedagogical toolkit. The experts stress 
the responsibility of the social empowerment of cultural institutions, the importance of sensitizing and integrated programs for the healthy to develop a more accepting, tolerant society, leading to self-experience experiences (Dabi-Farkas 2019).

The Metropolitan Circus in Budapest successfully applies a completely new method of education called circus pedagogy and "social circus". Circus pedagogy focuses on creating chances and compensating for disadvantage. It is effectively able to help to develop the skills and competencies of disadvantaged children and young people, to overcome physical and social disadvantages, and to improve their well-being. A circus art production connects the arts and sciences, encapsulates a variety of knowledge and abilities, thus allowing the interconnection of different learning areas, understanding, and experiencing the context of phenomena. Active action, trying, experiencing, performing, physical pleasure, fun, success during learning, which increases the motivation to overcome the disadvantages of learning (Joó 2019). But we also see a school example, the teachers of the Bárczi Gusztáv school have started juggling techniques in the development of people with disabilities, giving their students skills in a playful form that requires serious coordination of movement, concentration, and social cooperation ${ }^{5}$.

\section{CONCLUSION}

Good practices in Hungarian and international museum pedagogy indicate that most museums quickly reflect on the changing visitor needs. The relationship between the museum and the school is becoming ever closer, the museum sessions strive to live up to the new learning habits. They develop their programs in the spirit of the constructivist teaching method, visitors as learners are actively involved in a process of meaning and knowledge construction as opposed to passively receiving information. They understand and use actively the priority of connectivism, which determined learning in a digital age. Learning does not simply happen within an individual, but within and across the networks. Pedagogy of connectivism is a form of experiential learning formed by actions and experience over the idea that knowledge is a proposition (Hein 2004b; Hooper-Greenhill 2004).

The Hungarian museums reflect (mainly from Budapest) on the specific needs of people with special

\footnotetext{
5 “A cirkuszpedagógia készségfejlesztő hatásai." Józsefváros Újság, October 04,. 2018. Accessed March 05, 2020. https://jozsefvaros.hu/ hir/6100/a-cirkuszpedagogia-keszsegfejleszto-hatasai
}

educational needs, the disadvantaged, and the different generations. At the same time, we have to underline that museums and schools face many problems. Several major museums have been closed due to renovation works. Their activities are limited to smaller co-museums, which have advantages (theme-specific) and disadvantages (lack of large comprehensive exhibitions). Both types of institutions are characterized by their changing financial situation, often limiting their potential.

At the same time, excellent professionals ${ }^{6}$, many good projects, and a rich training offer help the museum pedagogy in the Hungarian culture. Events at museums and exhibition venues strive to show not only the objects but also to deepen their message and update problems with interactive forms of activity. Different forms of experiential learning, online and offline learning make a big contribution to complementing the school knowledge canon. Development of education in the museum based on research projects in Hungary too ${ }^{7}$.

Of course, out-of-school learning cannot be a substitute for formal education within an organized school framework, but a compliment to it. Visiting the museum should not be seen as a mere recreation or excursion, although there is a great difference between schools in this area. Fortunately, there are purposefully developed, prepared, didactically constructed extracurricular occupations (Füz 2017). Success requires knowledge of context, the appropriate method, knowledge of the mediated content (subjects), understanding the theories of learning and teaching, and speaking for mediation (Griffiths, Aerni and King 2007). Extra-curricular (museum education) is information-rich, interdisciplinary, and more innovative and interesting for students compared to traditional school frameworks. Education specifically based on student activity can significantly increase learning motivation (Black 2012; Fägerstam 2012; Füz 2018; Waite 2011).

The richness and methodological variety of museums help to address cultural diversity in the student communities of schools. Museum educators can greatly support the work of teachers, and cooperation between schools and museums aims to promote this. The raising of digital exhibitions, learning programs, and projects give us the motivation to analyse the new digital message of museums in the $21^{\text {st }}$ century.

\footnotetext{
${ }^{6}$ The ruling about educators in museums permits of free choice for leaders of museum. They can employ teachers, educators without special training (degree) of Education in Museum.

${ }^{7}$ Initiators of research projects are the universities in cooperation with museums (for example Pécs, 2018) and European Union in cooperation with Centre of Museum Learning and Methodology (Szentendre, 2017).
} 


\section{REFERENCES}

Anderson, David. 2008. Learning in Museums. New Perspectives and Policies in the UK. In Museen neu denken. Perspektiven der Kulturvermittlung und Zielgruppenarbeit, edited by John. Harmut, Anja Dauschek, 93-99. Bielefeld: Transcript.

Bereczki Ibolya and Népessy Noémi ed. 2020. Múzeumi iránytü. Modern múzeumi interpretáció. Szentendre: Szabadtéri Néprajzi Múzeum - Múzeumi Oktatási és Módszertani Központ. https://mokk.skanzen. hu/admin/data/file/20200315/muzir23_online.pdf Accessed: March 28, 2020.

Binkowski, Annemarie. 2009. Museumspädagogik - Ein heterogener Wissenschaftsbereich. München/Ravensburg: Grin Verlag.

Black, Graham. 2012. Transforming museums in the twenty-first century. London. New York: Routledge.

Carr, David. 2001. "Balancing Act: Ethics, Mission, and the Public Trust." Museum News, 80: 25-33.

“A cirkuszpedagógia készségfejlesztő hatásai.” Józsefváros Újság, 04 October, 2018. https://jozsefvaros.hu/ hir/6100/a-cirkuszpedagogia-keszsegfejleszto-hatasai Accessed: March 05, 2020.

Coombs, Philip. H. 1969. Die Weltbildungskrise. Stuttgart: Ernst Klett Verlag.

Csapó, Benő. 1999. "Képességfejlesztés az iskolában - problémák és lehetőségek.” Új Pedagógiai Szemle 42: 4-13.

Dabi-Farkas, Rita. 2019. Esélyt a múzeummal - módszerek (vagy jó gyakorlatok) a megértési nehézséggel élők, mozgássérültek és látássérültek múzeumi fogadásához. In Neveléstudomány-Horizontok és dialógusok, edited by Aranka Varga, Helga Andl, Zsófia Molnár-Kovács, Pécs: MTA Pedagógiai Tudományos Bizottság PTE BTK Neveléstudományi Intézet. 71.

Daniela, Linda. 2020. Virtual Museums as Learning Agents. https://www.mdpi.com/2071-1050/12/7/2698/ htm\#B17-sustainability-12-02698 Accessed: Mai 28, 2020.

Dabi-Farkas, Rita. cur. 2018. Esélyt a múzeummal - módszertani kiadvány a hátrányos helyzetüek felzárkóztatásáért. Szentendre: Múzeumi iránytü 16. Szabadtéri Néprajzi Múzeum. https://mokk.skanzen.hu/admin/ data/file/20181119/2018-muzeumi-iranytu_16.pdf Accessed: February 28, 2020.

Delors, Jaques.1972/1997. Oktatás - rejtett kincs. A Jaques Delors vezette Nemzetközi Bizottság jelentése az UNESCO-nak az oktatás XXI. századra vonatkozó kérdéseiről. Transleted by Balázs Mihályné). Budapest: Osiris Kiadó.

Ébli, Gábor. 2005. Az antropologizált múzeum. Budapest: Typotex Kiadó.
Elwick, Alex. 2013. Non-formal learning in museums and galleries. PhD diss., New Castle University: School of Arts and Cultures. https://www.researchgate.net/publication/297577879_Non-formal_learning_in_museums_and_galleries\#fullTextFileContent Accessed: February 20, 2020.

Eshach, Haim. 2007. "Bridging in-school and out-ofschool learning: Formal, non-formal, and informal education." Journal of Science Education and Technology 16:171-190. Accessed: February 20, 2020.

Fägerstam, Emilia. 2012. Space and place. Perspectives on outdoor teaching and learning. Linköping: Department of Behavioural Sciences and Learning.

Farkas, Éva. 2014. A rejtett tudás: A nem formális környezetben szerzett tanulási eredmények hitelesítése. Szeged: SZTE JGYPK FI.

Frazon, Zsófia. 2018. ...Nyitott múzeum... Budapest: Néprajzi Múzeum.

Fűz, Nóra. 2017. “Iskolán kívüli színterek az általános iskolai oktatásban.” Magyar pedagógia 117:197-220. http://www.magyarpedagogia.hu/document/Fuz_ MPed20172.pdf Accessed: February 28, 2020.

Füz, Nóra. 2018. Az iskolán kívüli tanulás gyakorlatának, megitélésének és hatásának vizsgálata általános iskolás tanulók, pedagógusok és intézményvezetők körében, PhD diss., University of Szeged. http://doktori.bibl.uszeged.hu/9961/ Accessed: February 20, 2020.

Golnhofer, Erzsébet. 2003. “Tanulóképek és iskolaelméletek.” Iskolakultúra 13: 96-100.

Hein, George, E. 2004a. "John Dewey and Museum Education Curator." The Museum Journal. 47: 413-427.

Hein, George, E. 2004b. The constructivist museum. In The educational role of the museum, edited by Eilean Hooper-Greenhill. 73-79. London and New York: Routledge Taylor\&Francis Group.

Germán, Kinga. 2015. “Múzeumpedagógia előszó” Szociálpedagógia 3:3. http://real-j.mtak.hu/12222/8/szocped $\% 20$ 2015\%201-2\%20M\%C3\%BAzeumpedag\%C3\%B3gia.pdf Accessed: February 20, 2020.

Griffiths José-Marie, Donald W. King and Sarah E. Aerni, ed. 2007. The Use, Usefulness, and Value of Museums in the U.S. Toronto: Archives \& Museum Informatics. http://www.archimuse.com/mw2007/papers/griffiths/ griffiths.html Accessed: February 20, 2020.

Gombos, Szandra. 2011. "Kultúra és marketing a 21. században - A múzeumok szerepe az egyetemista hallgatók életében" In Felelős marketing, edited by János Fojtik, 879-888. Pécs: Pécsi Tudományegyetem Közgazdaságtudományi Kar. file://C:/Users/a/Downloads/Gombos\%20Szandra\%20-\%20Kultura\%20 es\%20marketing\%20a\%2021.\%20szazadban\%20(1). pdf Accessed: March 20, 2020. 
Halász, Gábor. 2001. Az iskolán kívül szerzett tudás elismerése: európai trendek. http://halaszg.ofi.hu/download/Iskolan_kivul.htm Accessed: March 04, 2020.

Hegedűs, Anita. 2017. “21. századi múzeumpedagógia az egyetemisták szemével." Veritatis Imago 2: 20-34. http://veritatisimago.hu/ViII-Hegedus_A.pdf Accessed: February 20, 2020.

Herles, Diethard. 1998. Das Museum und die Dinge. Wissenschaft, Präsentation, Pädagogik. Frankfurt/Main, New York: Campus Verlag GmbH.

Hirzy, Ellen, Cochran ed. 1992. Excellence and Equity. Washington DC: American Association of Museums.

Hooper-Greenhill, Eilean. 2004. "Museum learners as active postmodernists: contextualizing constructivism". In The educational role educational role of the museum, edited by Hooper-Greenhill, Eilean, 67-72. New York and London: Routledge Taylor\&Francis Group.

Hunyadi, Zsuzsa. 2005. "A kulturális fogyasztás és szabadidő eltöltésének néhány jellemzője”, In A magyar városok kulturális gazdasága, edited by György Enyedi, Krisztina Keresztély, 91-110. Budapest: MTA Társadalomkutató Központ.

Hümmer, Günter. 1980. "Darstellung der gegenwärtigen Situation der Museumspädagogik“. In Modellversuch "Soziale Studiengänge" an der GhK (cur.): Hümmer, Günter. 16-158. Kassel: Museumspädagogik Kassel. 17. Reihe Sozialarbeit.

Lyotard, Jean-François. 1993. "A posztmodern állapot." In A posztmodern állapot. Jürgen Habermas, JeanFrançois Lyotard, Richard Rorty tanulmányai, edited by Jürgen Habermas, Jean-François Lyotard, Richard Rorty, 7-146. Budapest: Századvég-Kiadó

Joó, Emese. 2019. "Cirkuszpedagógia." In Neveléstudomány-Horizontok és dialógusok, edited by Aranka Varga, Helga Andl, Zsófia Molnár-Kovács, Pécs: MTA Pedagógiai Tudományos Bizottság PTE BTK Neveléstudományi Intézet. 72.

Joó, Julianna. 2014. “A német művészetpedagógia története 1900-1980 között.” Neveléstudomány 4:79-91. http://nevelestudomany.elte.hu/downloads/2014/ nevelestudomany_2014_4_79-91.pdf Accessed: February 26, 2020.

Joó, Julianna. 2018. "Nemzetközi és hazai müvészeti múzeumok múzeumpedagógiai irányzatainak és módszereinek összehasonlító elemzése.” PhD diss., Eötvös Loránd University. https://ppk.elte.hu/file/Joo_Julianna_disszertacio.pdf Accessed: January 10, 2020.

Kapitány, Ágnes and Kapitány, Gábor. 2009. "A kultúra változása-Változások kultúrája.” In \{Vész\}jelzések a kultúráról. Jelentés a magyar kultúra állapotáról, edited by Tímea Antalóczy, László Füstös, Elemér Hankiss, 17-87. Budapest: MTA PTI.
Kelly, Linda. 2007. Visitors and learners: Adult museum visitors' learning identities. http://www.australianmuseum.com/ uploads/documents/9316/paper\%20 ceca\%202007.pdf Accessed: February 26, 2020.

Koltai, Zsuzsa. 2010. "Helyzetjelentés a hazai múzeumpedagógia eredményeiről és kihívásairól.” Iskolakultúra 20:107-123. http://epa.oszk. hu/00000/00011/00146/pdf/ Accessed: February 20, 2020.

Koltai, Zsuzsa. 2011. A múzeumi kultúraközvetítés változó világa: a múzeumi kultúraközvetítés pedagógiai és andragógiai szempontú vizsgálata. Iskolakultúrakönyvek 41. Veszprém: Iskolakultúra.

Koltai, Zsuzsa. 2012. “Innováció a múzeumpedagógiai elméletben és gyakorlatban.” Új Pedagógiai Szemle 62: 84-91.

Koltai, Zsuzsa. 2020. “Új trendek a múzeumandragógiában.” In Modern múzeumi interpretáció, edited by Ibolya Bereczky, Noémi Népessy, 211-225. Szentendre: Múzeumi iránytü 23. Szabadtéri Néprajzi Múzeum. https://mokk.skanzen.hu/admin/data/ file/20200315/muzir23_online.pdf Accessed: February $28,2020$.

Kovátsné, Németh, Mária. 2006. "Fenntartható oktatás és projektpedagógia”. Új Pedagógiai Szemle: 10: 68-74. https://epa.oszk.hu/00000/00035/00107/200610-mu-Kovatsne-Fenntarthato.html Accessed: February 24, 2020.

König, Gabriele. 2002. "Kinder - und Jugendmuseen Genese und Entwicklung einer Museumsgattung. Impulse für besucherorientierte Museumskonzepte." Berliner Schrift en zur Museumskunde, Band 16. Opladen: Leske und Budrich.

Lord, Barry and Lord, Gail Dexter. 2001. The Manual of Museum Exhibitions. Wallnut Creek: Altamira Press.

A Memorandum on Lifelong Learning of Commission of the European Communities. 2000. http://tvu. acs.si/dokumenti/LLLmemorandum_Oct2000.pdf Accessed: March 05, 2020. I

Molnár, Gyöngyvér. 2011. "Az információs-kommunikációs technológiák hatása a tanulásra és oktatásra.” Magyar Tudomány 172:1038-1047. http://epa.niif. hu/00600/00691/00093/pdf/mtud_2011_09_10381047.pdf Accessed: February 24, 2020.

Moskal, Patsy and Charles, Dzubian. 2001. Present and Future Directions for Assessing Cybereducation: The Changing Research Paradigm. 157-187. New York: Cybereducation, Liebert Inc.

Németh, András. 1996. A reformpedagógiai múltja és jelene. Budapest: Nemzeti Tankönyvkiadó.

OECD. 1996. Recognition of Non-formal and Informal Learning - Home. http://www.oecd.org/education/ 
skills-beyond-school/recognitionofnon-formalandinformallearning-home.htm Accessed: Mai 24, 2020.

Pásztor, János. 2000. “A posztmodern állapot." Református Szemle 4-5: 259.

Schütz, Helmut G. 2002. Kunst und Analyse der Betrachtung, Entwicklung und Gegenwart der Kunstrezeption zwischen Original und Medien. Hohengehren: Schneider Verlag.

Setényi János: 21. századi tanulási környezet. https://ofi. oh.gov.hu/tudastar/tanulas-fejlesztese/21-szazadi-tanulasi Accessed: Mai 28, 2020.

Simon, Nina. 2010. The Participatory Museum. Santa Cruz: Museum 2.0. http://www.participatorymuseum. org/ Accessed: February 26, 2020.

Somogyi-Rohonczy, Zsófia. 2019. "A múzeumpedagógia szerepe a tolerancia növelésében.” In Neveléstudomány-Horizontok és dialógusok, edited by Aranka Varga, Helga Andl, Zsófia Molnár-Kovács, Pécs: MTA Pedagógiai Tudományos Bizottság PTE BTK Neveléstudományi Intézet.

Soós, Andrea. 2016. "Múzeumosan látni a világot." Interview: Frazon Zsófiával. A Múzeum: a lassú műfaj címủ kiállítás kurátorával.” http://tranzitblog.hu/ muzeumosan-latni-a-vilagot/ Accessed: March 20, 2020.

Tripps, Manfred. 1990. Was ist Museumspädagogik? In: Schmeer-Sturm, Marie-Louise, Thinesse-Demel, Jutta, Ulbricht, Kurt and Vieregg, Hildegard ed. Museumspädagogik. Grundlagen und Praxisbericht. Baltmannsweiler: Schneider.

Vásárhelyi, Judit. cur. 2010. Nemzeti Környezeti Nevelési Stratégia. Alapvetés 2010. Budapest: Magyar Környezeti Nevelési Egyesület.

Vieregg, Hildegard, Schmeer-Sturm, Marie L, ThinesseDemel, Jutta and Ulbricht, Kurt. 1994. Museumspädagogik in neuer Sicht - Erwachsenenbildung im Museum. Vol. 1-2. Hohengehren: Schneider Verlag.

Waite, Sue. 2011. "Teaching and learning outside the classroom: personal values, alternative pedagogies and standards." Education 1:13-13; 65-82. 